Artikel Konseptual

Submitted: 4 Mei 2019

Accepted: 27 Juni 2019

Published: 30 Juni 2019

\title{
INTERNALISASI NILAI KEARIFAN LOKAL INDONESIA MELALUI PEMBELAJARAN SEJARAH UNTUK MEMBANGUN KARAKTER GENERASI MUDA JAMAN NOW
}

\begin{abstract}
Asyif Awaludin Romadhoni*, Dha Widhi Witir
asyifawaludinromadhoni@gmail.com

Pendidikan Sejarah, Fakultas IImu Sosial, Universitas Negeri Yogyakarta

Abstract: Indonesia is a diverse country. This diversity provides great potential, especially cultural diversity and the value of local wisdom which is a socio-cultural reflection of Indonesian society. This needs to be continued and taught to the younger generation, developed, and maintained its distinctive character in the midst of globalization. One way is to integrate education that instills the value of local wisdom into learning activities in Indonesian History and History subjects. Indonesian History and History are compulsory subjects, seen to be able to foster the love of the homeland, and foster the character of Indonesia. This is similar if integrated with the value of Indonesian local wisdom. The internalization of the value of Indonesian local wisdom in the subjects of Indonesian History and History can be carried out by using learning methods, teaching materials, learning media, and learning resources that are liked and in accordance with the characteristics of the young generation of Indonesia today.
\end{abstract}

Key words: internalization, character, value of local wisdom, learning history.

\section{PENDAHULUAN}

Indonesia adalah negara yang ikut tergabung di dalam berbagai organisasi internasional diantaranya ASEAN, PBB, G-20, dan beberapa organisasi internasional lainnuya. Berbagai kebijakan internasional tersebut tentu saja berdampak besar terhadap Indonesia, salah satunya adalah Masyarakat Ekonomi ASEAN (MEA) yang dicanangkan sejak akhir tahun 2015 lalu. MEA merupakan realisasi pasar bebas di Asia Tenggara yang bertujuan untuk mewujudkan kawasan yang berdaya saing tinggi di dunia Internasional. Sejalan dengan tujuan tersebut, banyak negara di Asia Tenggara mulai melebarkan sayap JPSI, Vol. 2, No. 1, 2019 
ke negara lain untuk mengembangkan dan memajukan kegiatan ekonominya. Hal tersebut akhirnya menyebabkan batas antar negara di kawasan Asia Tenggara menjadi semakin kabur. Lebih dari itu, dampak lainnya adalah berkaitan dengan kehidupan sosiokulutural, kebudayaan masing-masing negara menjadi saling bercampur dan terjadi penetrasi budaya dari asing.

Penetrasi budaya asing yang terjadi di Indonesia merupakan dampak negatif dari adanya kerja sama antar negara di dunia. Hal itu terjadi karena lalu lintas budaya antarwilayah dunia berjalan lancar tanpa ada hambatan yang berarti. Batas-batas kedaulatan negara bahkan tidak mampu menahan masuknya budaya dari negara lain meskipun budaya itu memiliki perbedaan besar. Akibat dari situasi tersebut, maka Indonesia menjadi salah satu pasar potensial berkembangnya budaya asing milik negara maju berkekuatan besar. Selain itu, beberapa kebudayaan Indonesia seperti batik juga sempat di akui sebagai kebudayaan Malaysia. Hal ini tentu sangat membahayakan bagi kelangsungan dan kelestarian kebudayaan lokal Indonesia. Berdasarkan situasi tersebut, Ahmad Safril Mubah berpendapat bahwa situasi atau keadaan seperti itu akan mengancam budaya-buaya lokal yang telah lama mentradisi dalam kehidupan sosiokultural masyarakat Indonesia (Mubah, 2011 :302-308).

Seiring dengan berbagai peristiwa pencurian dan penetrasi budaya dari negara lain yang semakin menggerus kebudayaan lokal Indonesia, maka seharusnya perlu adanya upaya inovatif untuk mengembalikan eksisteni budaya lokal. Sebab, kebudayaan yang dimiliki oleh Bangsa Indonesia adalah bekal awal negara ini dalam mengahadapi persaingan dengan negara lain di berbagai bidang di samping Sumber Daya Manusia yang berkualitas dan ketahanan politik dalam negeri. Hal ini sejalan dengan pernyataan Citrawan bahwa keragaman budaya Indonesia merupakan modal besar untuk membawa bangsa ini maju sejajar dengan negara-negara besar lainnya. Belum lagi potensi industri MICE (Meeting, Incentive, Confference, and Exhibition) yang memanfaatkan kebudayaan lokal turut serta memberikan peluang besar perekonomian Indonesia menghadapi pasar bebas dunia (Harison, 2012: 16).

Upaya membangun ketahanan budaya Bangsa Indonesia belum menunjukkan hasil yang signifikan hingga dewasa ini. Ketahanan budaya Bangsa Indonesia masih rentan seiring dengan semakin derasnya arus persaingan bebas dunia. Hal lain yang menyebabkan rentannya ketahanan kebudayaan Indonesia adalah karena adanya disorientasi tata nilai, 
krisis identitas, dan rendahnya daya saing bangsa. Krisis ketahanan budaya Bangsa Indonesia merupakan indikasi dari adanya krisis identitas negeri ini. Terjadinya krisis identitas tersebut bersamaan dengan rendahnya daya saing hasil karya bangsa telah mengakibatkan semakin melemahnya rasa percaya diri dan inferioritas serta sikap ketergantungan bangsa terhadap negara lain. Kondisi ini akan lebih jauh menyuburkan sikap rendahnya apresiasi masyarakat terhadap hasil karya dan kekayaan budaya nasional Bangsa Indonesia. Di samping itu, menipisnya semangat nasionalisme tersebut juga sebagai akibat dari lemahnya kemampuan bangsa dalam mengelola keragaman yang menjadi ciri khas Bangsa Indonesia.

Ahmad Safril Mubah berpendapat bahwa upaya-upaya pembangunan jati diri bangsa Indonesia, termasuk di dalamnya penghargaan pada nilai budaya dan bahasa, nilai solidartias sosial, kekeluargaan dan rasa cinta tanah air dirasakan semakin memudar (Mubah, 2011, 304). Budaya lokal yang sesuai karakter bangsa semakin sulit ditemukan, sementara itu budaya global lebih mudah merusak. Potensi keanekaragaman kebudayaan yang dimiliki oleh Bangsa Indonesia seharusnya bisa lebih dioptimalkan lagi. Jangan sampai keragaman justru dijadikan sebagai ancaman terjadinya disintegrasi bangsa, apalagi di tengah persaingan dunia seperti saat ini karena dalam menghadapi pasar bebas dunia, kesatuan dan persatuan bangsa juga merupakan faktor penting untuk dapat memenangkan kompetisi tersebut. Tanpa kesatuan dan persatuan bangsa tersebut, negara tidak akan kuat menghadapi gempuran kebudayaan dari luar.

Penanaman nilai kearifan lokal sejak dini selain bertujuan untuk menyiapkan generasi emas Indonesia tahun 2045. Momentum Indonesia emas di tahun 2045 merupakan sebuah tantangan dan juga peluang. Disebut peluang karena di tahun 2045, negeri ini akan dihuni oleh Sumber Daya Manusia produktif yang banyak. Hampir sebagian besar generasi muda bergantung pada teknologi. Maka dari itu, perlu adanya upaya yang tepat untuk mengarahkan generasi muda dalam memanfaatkan berbagai kemajuan secara bijak (Romadhoni, 2017:17). Akan tetapi kemajuan-kemajuan tersebut membuat sebagian generasi muda Indonesia saat ini terlena sehingga mengalami krisis identitas. Krisis identitas tersebut perlu diatasi kembali dengan cara penguatan lokalitas. Di sini tidak hanya unsur kebudayaan dan keberagaman Indonesia saja yang dikuatkan tetapi harus terdapat tokoh yang menjadi salah satu teladan bagi generasi muda.

Penanaman kearifan lokal dapat dilakukan dengan berbagai cara, salah satunya adalah melalui pendidikan. Dwi Siswoyo menjelaskan bahwa salah satu fungsi pendidikan 
adalah direktif, di mana pendidikan dipandang untuk menyiapkan manusia sebagai tenaga kerja dan menyiapkan warga negara yang baik (Siswoyo, 2016: 20-21). Berdasarkan hal tersebut, pendidikan tidak bisa dipisahkan dari peran guru sebagai tenaga pengajar. Baik buruknya pendidikan berkaitan erat dengan kompetensi serta kemampuan guru selama mengajar dan sarana prasarana yang mendukung kegiatan tersebut. Sarana dan prasarana tersebut salah satunya berkaitan dengan metode serta media pembelajaran yang diterapkan. Oleh sebab itu guru harus mengolah proses belajar mengajar yang memberikan rangsangan kepada siswa dalam kegiatan belajar. Sistem pembelajaran yang tidak bervariasi akan membuat siswa cenderung jenuh dan bosan. Keterlibatan siswa dalam proses belajar menandakan berjalannya proses belajar yang aktif. Hal tersebut perlu didorong untuk menciptakan suasana belajar yang demokratis, menarik dan menyenangkan, sehingga siswa dapat menjadi tertarik dan termotivasi untuk belajar.

Penanaman nilai-nilai kearifan lokal melalui pendidikan perlu dikemas dengan berbagai cara. Terlebih lagi saat ini tantangan dunia semakin besar dan dampak negatif globalisasi semakin berkembang di kalangan generasi muda. Dalam kajian ini, penulis tertarik untuk mengkaji cara menanamkan nilai kearifan lokal melalui pendidikan di era milenial saat ini. Penulis akan mengkaji bagaimana problematika penanaman kearifan lokal di ranah pendidikan serta bagaimana upaya internalisasi nilai kearifan lokal terhadap generasi muda. Penulis mengangkat judul "Internalisasi Nilai Kearifan Lokal Indonesia Melalui Pembelajaran Sejarah untuk Membangun Karakter Generasi Muda Jaman Now". Harapan dari adanya kajian ini adalah memberikan gambaran problematika penanaman nilai kearifan lokal yang terjadi di sekolah. Setelah itu, penulis kemudian menawarkan solusi untuk mengatasi problematika tersebut sehingga dapat diterapkan oleh masyarakat.

JPSI, Vol. 2, No. 1, 2019 


\section{PENTINGNYA INTERNALISASI NILAI KEARIFAN LOKAL INDONESIA UNTUK GENERASI MUDA JAMAN NOW}

Indonesia merupakan sebuah bangsa yang terbentuk dari beragam kultur dan struktur sosial yang berbeda-beda. Kultur yang ada di negara ini sangat heterogen. Salah satu hal yang mempengaruhi keragaman kultur di negara ini adalah luas wilayah. Selain itu, Indonesia juga merupakan negara kepulauan terluas didunia yang memiliki kurang lebih 17.508 pulau besar maupun kecil. Pendapat tersebut sejalan dengan pernyataan Siagian (Sumardi, 2012) bahwa setiap wilayah di Indonesia memiliki sistem sosial dan budaya yang berbeda-beda antara satu wilayah dengan wilayah lain sebagai ciri khas yang unik dari setiap wilayah yang kemudian menjadi kan nya salah satu penanda jati diri bangsa yang harus dilestarikan. Kebudayaan nusantara tiap daerah berbeda-beda. Keanekaragaman budaya tiap daerah tersebut mengandung suatu perangkat budaya tertentu yang memiliki keunikan dalam pewarisan atau pelestariannya.

Keanekaragaman budaya di setiap daerah di Indonesia pasti melahirkan sebuah mekanisme kecerdasan lokal atau yang lebih dikenal sebagai kearifan lokal. Kearifan lokal merupakan pandangan hidup dan ilmu pengetahuan serta berbagai strategi kehidupan masyarakat yang berupa aktivitas masyarakat lokal dalam menjawab berbagai masalah dan tantangan dalam pemenuhan kebutuhan mereka. Hal tersebut tentu menyesuaikan dengan pandangan hidup masyarakat setempat agar tidak terjadi pergeseran nilai-nilai. Kearifan lokal pula dianggap sebagai salah satu sarana mengolah kebudayaan dan mempertahankan diri dari kebudayaan asing (Rahayu, 2017:57). Kearifan lokal dalam sebuah masyarakat dapat berwujud praktek sosial yang dilandasi sebuah kearifan dari budaya bisa berupa nilai, norma, etika, kepercayaan, adat istiadat, hukum adat, aturan khusus, dan berbagai wujud lainnya (Dwiningrum, 2016:45). Dalam kearifan lokal terdapat berbagai nilai-nilai luhur yang dapat direfleksikan dan diterapkan dalam kehidupan masyarakat untuk mencapai keselarasan sosial.

Nilai-nilai kearifan lokal yang dapat direfleksikan dalam kehidupan masyarakat sangat banyak, salah satunya terdapat di masyarakat Jawa tepatnya di Kemiri, Temanggung, Jawa Tengah. Di tempat tersebut terdapat sebuah tradisi Kadeso. Tradisi Kadeso merupakan wujud rasa syukur masyarakat Kemiri dalam wujud sedekah desa (Romadhoni, 2018: 33). Dalam tradisi tersebut, masyarakat mengungkapkan rasa syukur 
kepada Tuhan dengan cara melaksanakan khajatan serta makan bersama. Hal ini dilakukan secara bersama dengan seluruh masyarakat Desa Kemiri tanpa memandang jenis kelamin, usia, agama, dan kepentingan. Hal tersebut apabila direfleksikan maka terdapat berbagai nilai-nilai yang dapat diterapkan dalam kehidupan sehari-hari diantaranya adalah bersyukur kepada Tuhan, toleransi, kebersamaan, dan keselarasan sosial.

Selain di Kemiri, salah satu wujud kearifan lokal yang dimiliki masyarakat Indonesia terdapat di Madura. Kearifan lokal yang dimiliki oleh masyarakat Madura salah satunya adalah terdapat di rumah adat Madura. Berdasarkan observasi yang dilakukan oleh penulis pada tanggal 3 Oktober 2018, pada rumah adat masyarakat Madura terdapat beberapa ruangan khusus untuk menyimpan hasil tani dan hasil nelayan. Mayoritas masyarakat Madura tradisional bekerja sebagai petani dan nelayan. Biasanya setelah bekerja mereka meletakkan hasil panen dan hasil tangkapan laut mereka ke dalam sebuah ruangan khusus yang hanya berisi barang tersebut. Hasil tani dan hasil laut tersebut hanya dikelola di ruang tersebut sebelum dijual di pasar. Ruangan khusus tersebut sangat unik karena berukuran cukup luas yakni $5 \times 5$ meter dan dibangun khusus agar tidak mengganggu fungsi ruangan lain di rumah. Hal ini dapat direfleksikan bahwa masyarakat tradisional Madura menjaga estetika dan pekerja keras karena mau mengelola barang dengan baik sebelum didistribusikan kepada pelanggan.

Berdasarkan dua hal tersebut, nilai-nilai kearifan lokal perlu ditanamkan kepada seluruh kalangan, salah satunya adalah generasi muda. Penanaman nilai kearifan lokal sangat penting dilakukan mengingat saat ini perkembangan teknologi dan pengaruh globalisasi semakin menggerus identitas bangsa. Penanaman nilai kearifan lokal dapat dilakukan dengan berbagai cara salah satunya adalah pendidikan. Melalui pendidikan, manusia akan memperoleh berbagai pengetahuan dan nilai-nilai yang bertujuan untuk memanusiakan manusia. Pada hakikatnya manusia memperoleh pendidikan di tiga lingkungan yakni lingkungan keluarga, lingkungan sekolah, dan lingkungan masyarakat (Dwiningrum, 2016: 47). Sejak masih dalam kandungan ibu hingga terlahir di dunia, manusia mendapatkan pendidikan di lingkungan keluarga. Di sinilah keluarga berperan menanamkan nilai-nilai kearifan lokal dan membentuk identitas manusia. Setelah manusia beranjak dewasa, manusia memperoleh pendidikan di sekolah formal maupun sekolah informal. Manusia mendapatkan pengetahuan secara kognitif dan diasah kreativitasnya. Di samping itu, di sekolah pula manusia akan bertemu dengan hal yang baru daripada di rumah, Hal yang baru pula akan dijumpai manusia ketika terjun langsung di 
masyarakat. Manusia akan memperoleh beberapa hal baru dan tentu saja manusia perlu menyesuaikan diri agar dapat diterima oleh masyarakat. Termasuk di era globalisasi ini, beberapa hal baru yang dibawa oleh globalisasi pula merupakan pendidikan untuk manusia sehingga beberapa hal yang baik maupun buruk diterima sebagai pendidikan (Oviyanti, 2013: 1-14).

Dalam menghadapi krisis karakter generasi muda, peran pendidikan di lingkungan keluarga dan lingkungan sekolah sangat dibutuhkan sebagai penyaring hal negatif yang diperoleh saat mendapat hal baru di lingkungan masyarakat. Keluarga sendiri berperan sebagai orang pertama dalam pembentukan karakter generasi muda. Di dalam keluarga terdapat ayah dan ibu yang masing-masing memiliki cara dalam mendidik anaknya. Tetapi di era globalisasi saat ini terdapat fenomena ayah dan ibu membangun rumah tangga dengan cara masing-masing bekerja. Ketika ayah dan ibu bekerja, anak mengalami ketidakseimbangan dalam penanaman nilai dan karakter. Terlebih lagi di sekolah pun generasi muda masih memperoleh hal negatif dari teman-temannya. Sebagian ahli berpendapat bahwa sekolah merupakan miniatur masyarakat dikarenakan siswanya berasal dari berbagai latar belakang keluarga dan kondisi. Hal tersebut menuntut generasi muda untuk mampu menyesuaikan diri agar tidak terjerumus ke dalam hal yang tidak baik (Sukiyani dan Zamroni, 2014: 50-57).

Hal tersebut juga didukung teori trikon yang disampaikan oleh Ki hajar Dewantara tentang pentingnya pendidikan budaya untuk pembangunan bangsa, karakter, dan pelestarian budaya, yang dalam hal ini dapat kita kaitkan dengan pembelajaran yang bertujuan untuk internalisasi nilai kearifan lokal. Pendapat tersebut dituangkan dalam konsep trikon yang merupakan teori usaha pembinaan kebudayaan nasional yang terdiri dari kontinuitas (keberlanjutan budaya dan tradisi ke generasi selanjutnya), konsentris (sikap terbuka terhadap budaya luar), serta konvergensi (pemilahan kebudayaan asing) (Dwiningrum, 2016: 38-39). Hal tersebut masih relevan bila dijadikan dasar pentingnya pembelajaran yang bertujuan untuk internalisasi nilai kearifan lokal Indonesia dewasa ini. Maka, internalisasi nilai kearifan lokal Indonesia bagi generasi muda jaman now penting adanya untuk dilaksanakan. Hal tersebut dapat diintegrasikan dengan mata pelajaran yang diajarkan di sekolah. Salah satu mata pelajaran yang dapat diintegrasikan dengan internalisasi nilai kearifan lokal Indonesia adalah mata pelajaran Sejarah dan Sejarah Indonesia.

JPSI, Vol. 2, No. 1, 2019 
Mata pelajaran Sejarah dan Sejarah Indonesia memiliki kelebihan bila diintegrasikan dengan internalisasi nilai kearifan lokal Indonesia. Hal tersebut dapat dijelaskan dengan penyampaikan Sardiman (2015: 12) yaitu mata pelajaran Sejarah Indonesia dalam pelaksanaan kurikulum 2013 yang berlaku pada saat ini menyandang predikat mata pelajaran wajib bagi jenjang pendidikan SMA/MA/SMK/MAK. Di samping itu, mata pelajaran Sejarah dan Sejarah Indonesia dapat dijadikan sarana pemersatu dan memperkokoh semangat kebangsaan maupun rasa cinta tanah air. Maka, mata pelajaran Sejarah maupun Sejarah Indonesia kini dituntut memberikan pembelajaran efektif dan inovatif sebagai upaya penguatan kesadaran sejarah dan pembentukan watak, serta membagun peradaban bangsa yang bermartabat, mengantarkan pada pembentukan generasi muda yang berkarakter ke-Indonesiaan. Oleh karena itu, seolah ada ruang bagi kearifan lokal untuk berntegrasi dalam pembentukan karakter ke-Indonesian bagi generasi muda. Faktor lain yang mempengaruhi adalah adanya materi-materi yang bersinggungan dengan kearifan lokal yitu materi terkait sejarah kebudayaaan Indonesia.

\section{UPAYA INTERNALISASI NILAI KEARIFAN LOKAL INDONESIA MELALUI PEMBELAJARAN SEJARAH DI SEKOLAH}

\section{Internalisasi Internalisasi Kearifan Lokal Indonesia Melalui Pembelajaran Sejarah}

Upaya internalisasi kearifan lokal Indonesia dapat dilaksanakan melalui proses pembelajaran di sekolah. Hal tersebut dapat dilaksanakan melalui kegiatan pembelajaran. Salah satunya adalah mengintegrasikannya dengan pembelajaran sejarah. Dalam praktinya memerlukan sinergi dari tiga unsur utama dalam pendidikan. Unsur tersebut terdiri dari pendidik atau guru, peserta didik atau siswa, dan juga tujuan pendidikan. Ketika unsur tersebut dipandang penting untuk bekerja bersama karena ada sebuah kesinambungan antara tiap unsur yang tidak dapat terlepaskan (Siswoyo, 2013).

Guru memiliki peran yang besar dalam internalisasi nilai kearifan lokal Indonesia melalui kegiatan pembelajaran, khususnya pembelajaran sejarah. Akan tetapi, pembelajaran sejarah yang bertujuan untuk menanamkan nilai kearifan lokal memiliki beberapa masalah yang sifatnya konseptual seperti penyajian bahan pembelajaran dalam kurikulum yang disusun menjadi metode pembelajaran belum efektif. Materi pembelajarannya 
diasumsikan berbasis hafalan sedangkan ada beberapa materi yang dapat dibuat dengan peta konsep sehingga mempermudah siswa. Hal tersebut tentu dilatarbelakangi oleh proses pembelajaran yang kurang memotivasi siswa untuk mengikuti kegiatan belajar (Sumardi, 2012). Pengembangan layanan berupa mutu pembelajaran dari guru dituntut memiliki kemampuan dan keterampilannya secara profesional. Sehubungan dengan hal tersebut, penyajian metode pembelajaran harus sesuai dan dapat diterima oleh siswa dengan memperhatikan karakteristik siswa.

Melihat permasalahan yang terjadi, guru memiliki peran penting dalam mengatasinya. Salah satu caranaya adalah dengan mengimplementasikan suatu metode yang sesuai dengan kondisi dan karakteristik siswa dewasa ini. Hal tersebut senada dengan yang disampaikan oleh Slameto (2010: 65) bahwa metode mengajar mempengaruhi jalannya kegiatan pembelajaran karena metode pembelajaran yang pas membuat kegiatan pembelajaran lebih menyenangkan dan suasana pembelajaran yang kondusif bagi siswa. Olah karena itu, guru akan mudah menarik perhatian siswa dan siswa akan lebih aktif.

Di samping penerapan metode yang sesuai dengan karaktersitik siswa, guru dapat mencari atau membuat sumber belajar, bahan ajar, atau media pembelajaran yang tepat untuk menjawab permasalahan seperti yang dikemukakan di atas. Untuk menanamkan nilai kearifan lokal yang benar dan baik kepada peserta didik, maka peran guru sebagai perencana dan pengelola pembelajaran dituntut untuk lebih meningkatkan kemampuan professional mengajar. Untuk menciptakan suasana belajar yang menunjang proses pembelajaran serta mampu mengupayakan siswa terlibat secara aktif pada saat proses pembelajaran berlangsung. Namun, kebanyakan yang terjadi di lapangan adalah proses pembelajaran sejarah masih terjebak pada proses indoktrinisasi yang mengakibatkan siswa hanya terpaku pada kegiatan menghafal materi sehingga kemampuan yang disentuh hanyalah kemampuan berfikir tingkat rendah. Sedangkan yang diharapkan pada proses pembelajaran sejarah memerlukan keterlibatan siswa secara aktif untuk mengembangkan kemampuan berfikir kritis analisis agar proses pembelajaran tersebut dapat mengembangkan kemampuan berfikir kritis siswa (Wandari, 2015: 3).

Melihat praktek pembelajaran di atas, maka guru harus mencari atau membuat sumber belajar, bahan ajar, dan media pembelajaran yang tepat untuk menjawab permasalahan tersebut. Guru perlu sumber belajar, bahan ajar, dan media pembelajaran yang dapat membuat mata pelajaran sejarah menjadi mata pelajaran yang menarik dan 
tidak membosankan. Selain itu, guru juga harus memfasilitasi siswa untuk bisa belajar sejarah dengan menggunakan tingkat berfikir kritis. Agar pembelajaran itu menarik dan siswa dapat berfikir kritis, maka guru harus melibatkan siswa secara langsung dalam pembelajaran. Hal ini dilakukan agar siswa tertarik dan tertantang untuk mengikuti pelajaran tersebut. Dengan adanya ketertarikan dan tantangan tersebut, maka siswa akan aktif mengikuti proses pembelajaran. Keaktifan siswa dalam pembelajaran sejarah ini salah satunya dapat ditentukan oleh media yang digunakan oleh guru. Salah satunya bias berbentuk educational games

Dari berbagai penelitian yang dilakukan oleh lembaga terkait menunjukan bahwa permainan edukatif atau educational games dapat menunjang dan merangsang perkembangan multiple intelligence. Teori multiple intelligence sebuah teori yang menyatakan bahwa manusia memiliki beberapa kecerdasan. Kecerdasan yang dimaksud adalah bahwa seseorang memiliki kemampuan untuk menyelesaikan masalah yang memiliki nilai pada minimal suatu budaya. Adapun kecerdasan multiple intelligence yaitu antara lain Verbal-linguistik (kecerdasan dengan kata-kata), Logis-matematis (berkaitan dengan angka dan logika), Visual-Spasial (Berkaitan dengan gambar dan ruang), Kinestetik-jasmani (berkaiatan dengan koordinasi otot dan gerakan melakukan sesuatu), Musical (Berkaitan dengan pendengaran), Interpersonal (Berkaiatan dengan interaksi bersama orang lain), Intrapersonal (berkaitan dengan diri sendiri), dan naturalis (berkaitan dengan alam). Tokoh yang mengemukakakn teori multiple intelligence adalah seorang Psikologi dari Harvad, Howard Gender (Sugihartono, 2016: 78).

Di samping itu, diharapkan adanya sebuah sumber belajar, bahan ajar, dan juga media pembelajaran yang telah memperhatikan dan menerapkan sebuah bentuk teori efektifitas pemanfaatan media pembelajaran yaitu dengan menggunakan teori kerucut pengalaman belajar yang disampaikan oleh Edgar Dale. Teori tersebut menjelaskan suatu hasil belajar adalah hasil yang diawali dengan pengalaman langsung, benda tiruan, hingga lambang verbal yang bersifat abstrak, dan di puncak kerucut akan semakin abstrak terkait media tersebut. Hal tersebut disampaikan oleh Arsyad (2005: 172) pesan semakin abstrak bila hanya disampaikan dengan kata atau lambing saja, disbanding menggunakan menggunakan media.

JPSI, Vol. 2, No. 1, 2019 


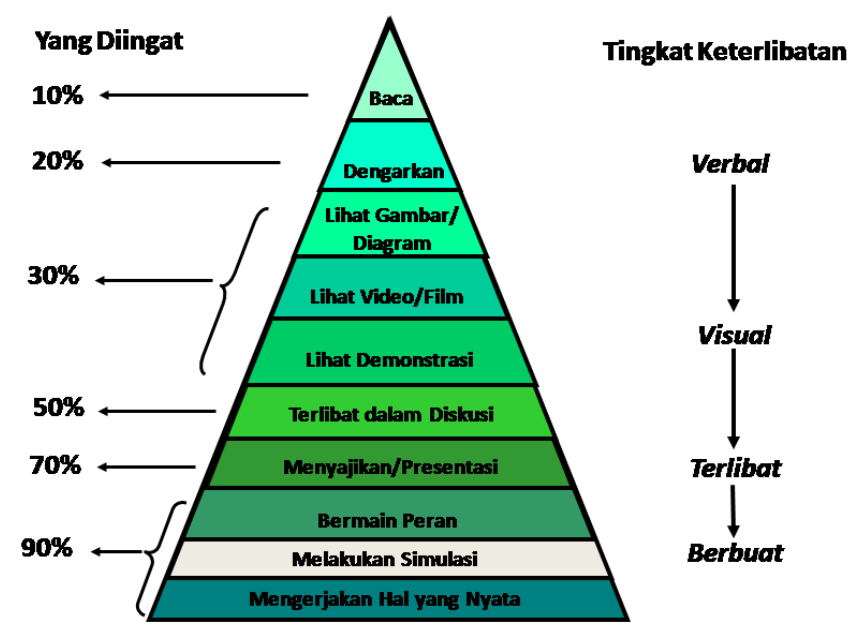

Gambar 1. Kerucut Pengalaman Belajar Dale

Sumber: https://kitchendecor.club/files/pengalaman-kerucut-edgar-dale.html

Penerapan sumber belajar, bahan ajar, dan media pembelajaran diharapkan dapat mengenalkan kebudayaan Indonesia kepada generasi muda. Setelah generasi muda mengenal budayanya sendiri, diharapkan jati diri bangsa yang merupakan nilai identitas masyarakat dapat dibangun secara kokoh dan diinternalisasikan secara mendalam. Penanaman nilai kearifan lokal sejak dini selain bertujuan untuk menyongsong masyarakat yang arif juga untuk menyiapkan generasi emas Indonesia tahun 2045. Momentum Indonesia emas di tahun 2045 merupakan sebuah tantangan dan juga peluang. Untuk menghadapi tantangan tersebut, generasi muda perlu memanfaatkan peluang agar dapat membangun Indonesia agar lebih maju dan beridentitas.

\section{Penerapan Model Epstein's Model For Parenting Dalam Rangka Pen- guataan Iklim Sekolah untuk Internalisasi Kearifan Lokal Indonesia di \\ Sekolah}

Sekolah harus mimiliki iklim yang sesuai dan mendukung usaha dalam rangka mewujudkan internalisasi atau proses penanaman yang mendarah daging tentang nilai kearifan lokal melalui pendidikan perlu dilakukan beragam upaya. Solusi pertama yang ditawarkan berdasarkan studi literatur yang telah dilakukan, penulis memilih model Epstein's Model for Parenting dalam Jurnal berjudul Ball State Child study center media JPSI, Vol. 2, No. 1, 2019 
strategy: Relating to millennial parents karya Edon dan Tierney Richelle yang diterbitkan oleh Ball State University tahun 2015. Jurnal ini memiliki studi kasus yang sama pada lembaga bimbingan belajar yang ada di Amerika dan mulai diterapkan di beberapa negara tersebut (Edon dan Richelle, 2013: 337-350). Namun pada kali ini, penulis mengganti objek pada lembaga bimbingan belajar menjadi sekolah. Hal ini dapat dijelaskan sebagai berikut.

Pertama, parenting, di mana orang tua memberikan informasi kepada sekolah akan kemampuan seorang anak dalam mengikuti pelajaran yakni hasil belajar di sekolah yang nantinya akan menjadi acuan dalam mengetahui kemampuan seorang anak tanpa adanya bias dengan keputusan orang tua. Kedua, communicating yakni sesi bimbingan konseling secara individual oleh sekolah dan peserta didik dengan harapan keinginan seorang anak secara edukatif dapat terpenuhi tanpa ada campur tangan dari keinginan orang tua mereka. Dengan demikian sekolah dapat memberikan treatment yang khusus kepada anak yang memang memiliki kebutuhan khusus.

Ketiga, voluntering yakni daya dukung orang tua dalam melihat proses pembelajaran di dalam kelas siswa dengan mengamati dan memberikan penilaian terhadap proses belajar di sekolah. Dengan ini orang tua bisa menilai kredibilitas pengajar serta kelemahan yang ada pada lembaga tersebut, dengan ini pula orang tua semakin tau minat seorang anak di masa depan. Keempat, learning at home. Di mana orang tua akan diberikan lembaran berupa rekam jejak proses pembelajaran anak di sekolah. Dengan ini orang tua bisa memastikan dengan menguji sejauh mana seorang anak memahami pelajaran dan di mana letak kelemahan seorang anak melalui tanya jawab dan bimbingan.

Kelima, decision making, yakni peran orang tua, anak, sekolah dalam menentukan model pembelajaran atau kurikulum yang cocok sesuai hasil pengamatan dan belajar di rumah seorang anak agar terjadi control feedback yang sinergis antara orang tua, anak dan lembaga bimbingan belajar. Hal ini bisa dilakukan dengan pertemuan orang tua, anak, sekolah. Keenam, collaborating with the community yakni kerjasama sekolah untuk mendatangkan keluarga-keluarga yang berhasil mencapai prestasi belajar yang tinggi melalui pola asuh orang tua dalam forum talkshow atau seminar. Dengan itu orang tua mendapat inspirasi dari orang tua yang lain tentang bagaimana cara mendidik anak yang efektif dan efisien. Keenam hal dari model Epstein's Model For Parenting diharapkan menjadi sebuah bentuk pendukung adanya proses internalisasi nilai kearifan lokal Indonesia melalui kegiatan pembelajaran, khususnya pembelajaran sejarah. 


\section{SIMPULAN}

Keanekaragaman kebudayaan Indonesia merupakan potensi yang besar bagi bangsa ini untuk membangun jatidiri bangsa di kalangan generasi muda. Hal itu terjadi karena kebudayaan Bangsa Indonesia adalah jati diri atau cerminan dari sosio kultural masyarakatnya. Itu artinya identitas dan jati diri masyarakat Indonesia dapat dilihat melalui kebudayaan yang dimiliki oleh Indonesia itu sendiri. Namun ditengah keberagaman dan perkembangan globalisasi, kebudayaan lokal Bangsa Indonesia justru tergusur oleh kebudayaan asing. Melihat hal tersebut, tentu itu adalah sebuah kesalahan besar mengingat selain kebudayaan Indonesia merupakan wujud dari jati diri bangsa. Melihat permasalah seperti diatas, maka perlu ada penyadaran sejak dini untuk terus melestarikan dan mengoptimalisasikan budaya serta nilai kerifan lokal Indonesia. Internalisasi nilai kearifan lokal Indonesia dapat diintegrasikan dengan mata pelajaran Sejarah dan Sejarah Indonesia. Cara internalisasi adalah dengan penggunaan metode pembelajaran, bahan ajar, media pembelajaran, dan sumber belajar yang disukai dan sesuai dengan karakteristik generasi muda Indonesia jaman now.

\section{DAFTAR PUSTAKA}

Anonim. (2019). Pengalaman Kerucut Edgar Dale. https://kitchendecor.club/files/pengalaman-kerucut-edgar-dale.html. (27 Maret 2019).

Arsyad, A. (2005). Media Pembelajaran. Jakarta: PT Raja Grafindo Persada.

Dwiningrum, S. I. A. (2016). Pendidikan Sosial Budaya. Yogyakarta: UNY Press.

Edon dan Richelle, T. (2015). "Ball State Child Study Center Media Strategy: Relating to Millennial Parents". Ball State University Journal. Volume III.

Harison, C. (2012). Konflik Sosial dan Ke(tidak)adilan Distributif. Jakarta: Badan Penelitian dan Pengembangan Hak Asasi Manusia.

Mubah, A. S. (2011). "Strategi Meningkatakan Daya Tahan Budaya Lokal dalam Menghadapi Arus Globalisasi". Jurnal Komunikasi. Volume XXIV, No. 4/2011. HIm. 302-308.

Oviyanti, F. (2013). "Tantangan Pengembangan Pendidikan Keguruan di Era Global". Jurnal Pendidikan Islam Nadwa. Volume VII, No.2/2013. HIm. 1-14.

Rahayu, P. (2017). Belajar Sejarah dari Lingkungan Sekitar. Surabaya: Raja Cipta.

Romadhoni, A. A., dkk. (2017). “C-HERO (Culture Heritage Board): Educational Games sebagai Media Pelestarian dan Pengoptimalisasian Pesona Budaya Nusantara bagi Z-Generation Indonesia". Publikasi Lomba Karya Tulis IImiah INSTINCT 2017 LPII Fakultas Ekonomi Universitas Riau 2017.

JPSI, Vol. 2, No. 1, 2019 
Romadhoni, A. A., dkk. (2018). "Harmoni Budaya dalam Kearifan Lokal melalui Akulturasi Buddhisme dan Kejawen sebagai Wujud Nilai-nilai Pendidikan Karakter pada Masyarakat Kemiri Temanggung Jawa Tengah". Laporan Hasil Penelitian Mahasiswa Fakultas IImu Sosial Universitas Negeri Yogyakarta Tahun 2018.

Sardiman. (2015). "Menakar Posisi Sejarah Indonesia pada Kurikulum 2013". Istoria. Volume $\mathrm{XI}, \mathrm{No.1/2015.} \mathrm{HIm.} \mathrm{1-13.}$

Siswoyo, D. (2016). Ilmu Pendidikan. Yogyakarta: UNY Press.

Slameto. (2010). Belajar dan Faktor yang Mempengaruhinya. Jakarta: Rineka Cipta.

Sugihartono. (2016). Psikologi Pendidikan. Yogyakarta: UNY Press.

Sukiyani, F. dan Zamroni. (2014). "Pendidikan Karakter dalam Lingkungan Keluarga”. Jurnal IImu-IImu Sosial Socia. Volume XI, No. 1/2014. HIm. 57-70.

Sumardi, T. (2012). “Penerapan Media Pembelajaran Kartu Permainan Sejarah Dalam Upaya Meningkatkan Aktivitas Belajar Siswa Pada Mata Pelajaran Sejarah Di Kelas X IPA 1 SMA Negeri 14 Bandung". Antologi Jurnal Sejarah dan Pendidikan Sejarah. Volume II, No. 2/2012.

Wandari, M. (2015). "Pengembangan SMADAM (Smart Media based on Nasionalism) Berbasis Adobe Flash Interaktif untuk Meningkatkan Pemahaman dalam Pelajaran Pendidikan Kewarganegaraan SMP" Artikel Hasil Hibah Penelitian Student Union Grant (SUG) Universitas Negeri Yogyakarta Tahun 2015. 